\title{
Analysis of formaldehyde content in salted fish at Ciroyom Market, Bandung City, Indonesia
}

\author{
Candra Utama $^{1}$, Nurwidiyanto ${ }^{2}$, Farhan Baehaki ${ }^{3}$, Sri Ekawati ${ }^{4}$ \\ ${ }^{1}$ Department of biology, Universitas Negeri Malang, Indonesia \\ ${ }^{2}$ School of Mathematic, Northeast Normal University, China \\ ${ }^{3,4}$ Medical Laboratory Technology, Institut Kesehatan Rajawali, Indonesia
}

\begin{abstract}
Salted fish is one of the processed fish products that are in great demand by the people of Indonesia. This type of preparation has good durability with natural processes. However, there are some cases that use chemicals as preservatives, such as formaldehyde. This study aims to determine the formaldehyde content in salted fish that is traded in the market in Indonesia. This research is descriptive and the samples were randomly taken from Ciroyom Market, Bandung City, Indonesia. The data were analyzed qualitatively to find out the physical characteristics of the salted fish. In addition, a quantitative analysis was also carried out to determine the level of formaldehyde present in salted fish using a UV-Vis spectrophotometer at a wavelength of $520 \mathrm{~nm}$. The results of the analysis showed that 4 of the 15 samples tested contained formaldehyde with a concentration of 0.033 $0.482 \mathrm{ppm}$. The characteristics of these samples physically also have similarities with the characteristics of fish containing formaldehyde, which are bright white and hard textured.
\end{abstract}

\section{KEYWORDS}

Salted fish, preservatives, formaldehyde, toxicology
ARTICLE INFO

Received: 27 June 2021

Accepted: 28 June 2021

Published: 29 June 2021

\section{INTRODUCTION}

Indonesia is an archipelagic country that has tremendous natural wealth. Indonesia's sea area is two-thirds of its land area, which is around 3.544 million $\mathrm{km}^{2}$ (Pursetyo, Thajaningsih, and Pramono, 2015). Therefore, one of Indonesia's development targets should be oriented towards the maritime sector, namely fisheries. One of the efforts made to encourage economic improvement in the fisheries sector in Indonesia is through the policy of accelerating marine and fisheries industrialization (Sianturi, Masinambow, and Londa, 2018). Thus, Indonesia has the opportunity to become the world's largest producer of fishery products (Kurniawan, 2017).

\footnotetext{
CONTACT Farhan Baehaki M) farhanbaehaki71@gmail.com

This is an Open Access article distributed under the terms of the Creative Commons Attribution-ShareAlike 4.0 International (CC BY-SA 4.0) License (https://creativecommons.org/licenses/by-sa/4.0/), which allows others to share the work with an acknowledgement of the work's authorship and initial publication in this journal.
} 
One of the popular fishery products in Indonesia is salted fish. Salted fish is fish that is preserved by a salting process. This method is a traditional method that does not require any equipment in preservation techniques (Zakaria, Sulastri, Sudding, 2014). However, the remaining water content in salted fish can cause spoilage so that its durability is limited. According to Habibah (2014), fish that have a high enough water content will decompose more quickly because bacteria are easy to grow. The preservation process at this time is mostly found using chemical substances. This aims to extend the durability of salted fish so that it can last a longer time. However, the thing that needs to be a concern is the use of harmful chemicals in the preservation process, one of which is formaldehyde. This is reinforced by several studies that examine the use of formaldehyde in salted fish. Research conducted by Habibah (2014) at a Traditional Market in Semarang City, Indonesia. The study showed that 9 and 41 samples of salted fish sold in 11 traditional markets in Semarang City were indicated to contain formaldehyde. Another study was conducted by Zakaria, Sulastri, and Sudding (2014) which showed as many as 10 of 14 salted fish samples in Semarang City contained formaldehyde in it. In addition, Fatimah, Astuti, and Awalia (2017) also conducted the same study where the results showed that there were 12 positive samples containing formaldehyde from 26 samples of salted fish sold at Beringharjo Market and Giwangan Market, Yogyakarta City, Indonesia.

The use of formaldehyde as a food preservative is strictly prohibited by the government of the Republic of Indonesia. This is stated in the Regulation of the Minister of Health of the Republic of Indonesia Number 722/Men.Kes/Per/IX/88 concerning Food Additives and Regulation of the Minister of Health Number 1168/Menkes/PER/X/1999 concerning Chemicals whose use is prohibited for food products. However, its use as a preservative is still carried out by producers or traders. Manufacturers or traders prefer to use formaldehyde to preserve fish because the price is cheaper, easy to obtain, and the preservation process is simple (Cahyadi, 2012). The low level of public knowledge about formaldehyde is one of the main factors causing formaldehyde abuse (Alsuhendra and Ridawati, 2013; Tatuh, Rorong, and Sudewi, 2016). Whereas formaldehyde can have a negative impact on body health (Alsuhendra and Ridawati, 2013; Wardani and Mulasari, 2016; Cahyadi, 2012; Heck, Casanova, and Starr, 1990). Based on these problems, the authors conducted a study to obtain an overview of the use of formaldehyde as a preservative for salted fish that is traded in the market in Bandung, Indonesia.

\section{LITERATURE REVIEW}

\section{Formaldehyde}

Formaldehyde is a solution that is commonly found in the market (Fatimah, Astuti and Awalia 2017). Formaldehyde has the trade name formaldehyde in water with levels of $30-40 \%$. Formaldehyde is an organic compound with a $\mathrm{CH}_{2} \mathrm{O}$ structure, resulting from incomplete combustion of a number of organic compounds (Male, Letsoin and Siahaya, 2017). The properties of formaldehyde are flammable, highly reactive, highly soluble in water, soluble in non-polar solvents, are strong reducing agents, volatile, have a sharp odor, are colorless, and have polymerized at room temperature (Alsuhendra and Ridawati). , 2013; Male, Letsoin and Siahaya, 2017). 


\section{Toxic effect of formaldehyde}

Formaldehyde is not a food additive because its use for food has been prohibited by the government through the Regulation of the Minister of Health of the Republic of Indonesia Number 722/Men.Kes/Per/IX/88 concerning Food Additives and Regulation of the Minister of Health Number 1168/Menkes/PER/X/1999 concerning Chemicals whose use is prohibited for food products because they are harmful to health. The negative effects of consuming foods containing small amounts of formaldehyde are not felt immediately, but these effects will be felt after several years or decades to come. If the formaldehyde content in the body is high after accumulation, formaldehyde will react chemically with almost all substances in the cells (Cahyadi, 2012).

Several studies have shown the reactive and carcinogenic properties of formaldehyde, such as leukemia and nasopharyngeal cancer (Tang, et al., 2009; Freeman et al. 2009; Hauptmann et al. 2009; Scheuplein, 1985; Restani and Galli, 1991). ; Zhao, et al., 2021; Bernardini et al., 2020). According to Hasmalina, Alfayed and Helvina (2018), apart from being influenced by the level of formaldehyde that enters the body, the negative effects of formaldehyde on health also depend on contact or the way formaldehyde is exposed to the body. When formaldehyde enters through the breath, the effects felt are burning and irritation of the nose and throat, difficulty breathing, coughing, shortness of breath, excessive chest pain, fatigue, headache, palpitations, nausea, vomiting, kidney injury. , sleep disturbances, irritability, loss of concentration and memory, menstrual disorders, pneumonia, swelling of the lungs and lung cancer (Tang, et al., 2009; Heck, Casanova, and Starr, 1990). At high concentrations it causes death (Alsuhendra and Ridawati, 2013). When formaldehyde enters through the skin, the effects felt are redness, itching, hardening of the skin, numbness, burning, damage to the fingers and inflammation of the skin that causes bubbles (Alsuhendra and Ridawati, 2013; Heck, Casanova, and Starr). , 1990). If formaldehyde enters through the eyes, the effects that will be felt are eye irritation, itchy red eyes, watery eyes, blurred vision, damage to the lens, inflammation of the eye membranes and blindness. And when formaldehyde enters through the digestive tract, the effects that will be felt are nausea, vomiting, burning throat and stomach, pain when swallowing, diarrhea, severe stomach pain, hypotension, headache, dizziness, heart problems, blue skin, loss of vision, seizures. , coma and death (Alsuhendra and Ridawati, 2013; Heck, Casanova, and Starr, 1990). According to Yuswanto in Sinaga (2009), formaldehyde in the body can be absorbed through the digestive tract because it is easily soluble in water. Once absorbed, formaldehyde is rapidly distributed to the muscles, intestines, liver, and other tissues. Formaldehyde is metabolized to formic acid by the enzyme formaldehyde dehydrogenase. Formaldehyde itself is a normal intermediate metabolite in cells in the metabolism of serine, glycine, methionine, and choline in the human body. Formaldehyde is secreted in the form of formic acid which is excreted through the kidneys and in the form of carbon dioxide through the lungs.

\section{Formaldehyde abuse}

Formaldehyde is a chemical compound that has antimicrobial activity so that it can kill bacteria, even viruses (Sari, Asterina and Adrial, 2014; Cahyadi, 2012). Therefore, formaldehyde is used as an effective disinfectant against vegetative bacteria, fungi or viruses, although it is less effective against bacterial spores 
(Hasna, Sangi and Wuntu, 2017). Other functions of formaldehyde are insect repellent, coloring agent, glass making material, explosive, gelatin and paper coating hardener, fertilizer making material, and cosmetic product preservative (Hasna, Sangi and Wuntu, 2017).

With the characteristics of formaldehyde that can function as an antimicrobial, formaldehyde is widely misused for its function as a food preservative. Whereas according to the Regulation of the Minister of Health of the Republic of Indonesia Number 722/Men.Kes/Per/IX/88 concerning Food Additives and Regulation of the Minister of Health Number 1168/Menkes/PER/X/1999 concerning Chemicals whose use is prohibited for food products, formaldehyde is one of the one type of additive that may not be used for food, in addition to 8 other types of ingredients, namely boric acid and its compounds, salicylic acid and its salts, diethyl pyrocarbonate, dulcine, potassium chlorate, chloramphenicol, brominated vegetable oil and nitrofurazone. Alsuhendra and Ridawati (2013) and Cahyadi (2012) said that there are several reasons for the use of formaldehyde as a preservative by producers or traders, namely 1) the price is cheaper; 2) the amount of formaldehyde required to preserve is less than other preservatives; 3 ) easy to use; 4) the time required for the preservation process is relatively short; 5) easy to obtain in large quantities; and 6) lack of knowledge and public awareness about the dangers of formaldehyde. Generally, foods that contain formaldehyde have characteristics, namely the color is brighter, not infested by flies, and the texture is harder (Hastuti, 2017).

\section{METHODS}

The research was conducted qualitatively and quantitatively. A qualitative study was conducted by observing the characteristics of salted fish and the resistance of salted fish. While quantitative analysis was conducted to determine the level of formaldehyde in salted fish. This analysis was carried out using a UV-Vis spectrophotometer at a wavelength of $520 \mathrm{~nm}$ (Male, Letsoin, and Siahaya, 2017). Qualitative data and quantitative data will be analyzed to see the trend of the data.

\section{Sample preparation}

The samples are various types of salted fish that are traded in Ciroyom Market, Bandung City, Indonesia. Samples were taken using total sampling technique, where all types of salted fish were used as samples. A total of 15 samples were used in this study, consisting of anchovy salted fish, Cucut salted fish, bloated salted fish, Peda salted fish, and Sepat salted fish.

\section{Qualitative Analysis}

This analysis was carried out by observing the physical characteristics of salted fish. In addition, the durability of salted fish was also observed by storing it in a dry place until microorganisms developed in the fish.

\section{Creating standard curves}

Male, Letsoin, and Siahaya (2017) explain that the standard curve can be made by making a series of standard solutions with a concentration of 1 ppm; 1.5 ppm; 2 ppm; 2.5 ppm; and 3 ppm. Each solution was taken as much as $5 \mathrm{ml}$ and added with $5 \mathrm{ml}$ of $0.5 \%$ chromatic acid solution in $60 \%$ sulfuric acid. Then the 
solution was heated for 15 minutes at $100{ }^{\circ} \mathrm{C}$ and cooled. The absorbance of the five solutions was measured using a UV-Vis spectrophotometer at a wavelength of $520 \mathrm{~nm}$. The data obtained is then plotted in the form of a curve.

\section{Preparation of test solutions and measurement of formaldehyde levels in samples}

Preparation of test solutions and test measurements were carried out based on the procedure developed by Male, Letsoin and Siahaya (2017). A total of 5 grams of the sample was crushed, put into a beaker, and added with $50 \mathrm{ml}$ of distilled water. The solution was filtered and the filtrate was added with a $0.5 \%$ solution of chromotropic acid in $60 \%$ sulfuric acid. The solution was heated for 15 minutes at $100{ }^{\circ} \mathrm{C}$, then cooled. After cooling, the absorbance was measured using a UV-Vis spectrophotometer at a wavelength of $520 \mathrm{~nm}$.

\section{RESULTS \\ Qualitative analysis results}

Qualitative analysis was conducted to see the physical characteristics of the salted fish used as samples. The analysis was carried out by referring to the characteristics of salted fish containing formaldehyde. This analysis was also carried out to see the durability of salted fish. The results of the analysis can be seen in Table 1.

Table 1. Results of the analysis of the physical characteristics of salted fish

\begin{tabular}{ccccc}
\hline Types of Salted Fish & Sample Code & Color & Texture & Durability (day) \\
\hline \multirow{4}{*}{ Teri salted fish } & P1T & Brown & Mushy & $1-2$ \\
& P2T & Brown & Mushy & $2-3$ \\
& P3T & Brown & Mushy & $1-2$ \\
\hline \multirow{3}{*}{ Peda salted fish } & P1P & Brown & Mushy & $2-3$ \\
& P2P & Brown & Mushy & $2-3$ \\
& P3P & Brown & Mushy & $1-2$ \\
\hline \multirow{5}{*}{ Cucut salted fish } & P1C & Brown & Mushy & $2-3$ \\
& P2C & Bright white & Slightly hard & $4-6$ \\
& P3C & Bright white & Slightly hard & $3-5$ \\
\hline \multirow{3}{*}{ Sepat salted fish } & P1S & Brown & Mushy & $2-3$ \\
& P2S & Brown & Mushy & $1-2$ \\
& P3S & Brown & Mushy & $2-3$ \\
\hline \multirow{3}{*}{ Kembung salted fish } & P1K & Bright white & Slightly hard & $4-6$ \\
& P2K & Brown & Mushy & $1-2$ \\
& P3K & Bright white & Slightly hard & $4-5$ \\
\hline
\end{tabular}

\section{Standard curve}

A standard curve was made to determine the level of formaldehyde present in salted fish. This curve 
is made by plotting the concentration and absorbance data of the standard solution. The absorbance measurement data can be seen in Table 2.

Table 2. Result of absorbance measurement of standard formaldehyde solution

\begin{tabular}{cc}
\hline Concentration (ppm) & Absorbance \\
\hline 1.0 & 0.543 \\
1.5 & 0.628 \\
2.0 & 0.741 \\
2.5 & 0.832 \\
3.0 & 0.952 \\
\hline
\end{tabular}

The results of the data plot in Table 2 will form a standard curve. The standard curve will obtain a line equation that can be used to calculate formaldehyde levels (see Figure 1).

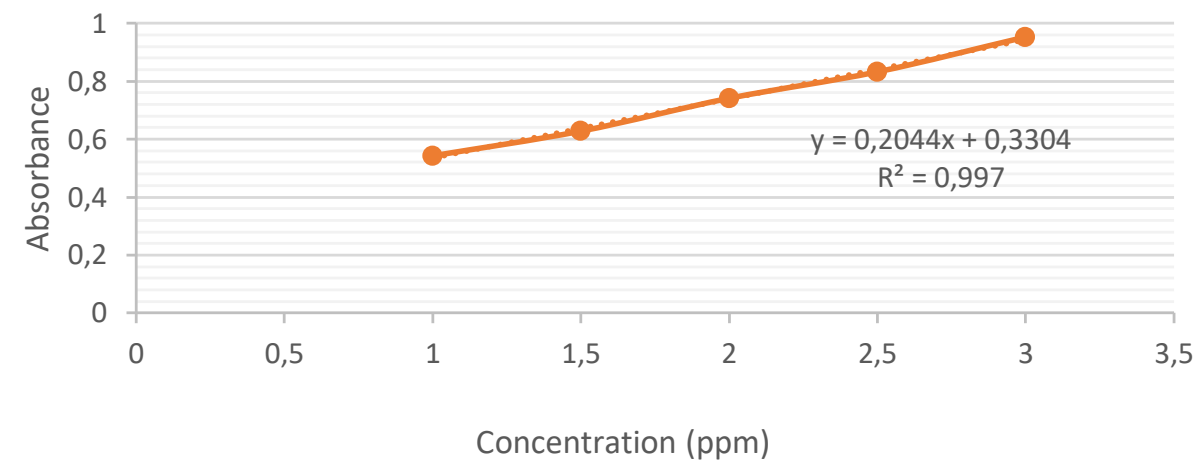

Figure 1. Standard curve of formaldehyde standard solution

\section{Formaldehyde levels in salted fish}

Measurement of formaldehyde levels was carried out by measuring the absorbance of the sample and calculation using the equation in Figure 2. The data in Figure 2 shows that the equation of the line obtained is $y=0.2044 x+0.3304$. By calculating using this line equation, the formaldehyde content data is obtained in Table 3. The data in Table 3 shows that most of the samples do not contain formaldehyde with. However, in some salted fish it was confirmed the presence of formaldehyde, namely in the P2C, P3C, P1K, and $\mathrm{P} 3 \mathrm{~K}$ samples. Where the highest formaldehyde content was in the P3C sample with a concentration of $0.482 \mathrm{ppm}$.

Table 3. Results of measurement of formaldehyde levels in salted fish samples

\begin{tabular}{ccc}
\hline Types of Salted Fish & Sample Code & Formaldehyde level (ppm) \\
\hline \multirow{3}{*}{ Teri salted fish } & P1T & -0.422 \\
& P2T & -0.476 \\
& P3T & -0.505 \\
\hline \multirow{3}{*}{ Peda salted fish } & P1P & -0.500 \\
& P2P & -0.515 \\
& P3P & -0.403 \\
\hline
\end{tabular}




\begin{tabular}{cll}
\hline \multirow{3}{*}{ Cucut salted fish } & P1C & -0.412 \\
& P2C & 0.448 \\
& P3C & 0.482 \\
\hline \multirow{3}{*}{ Sepat salted fish } & P1S & -1.019 \\
& P2S & -0.481 \\
& P3S & -0.525 \\
\hline \multirow{3}{*}{ Kembung salted fish } & P1K & 0.252 \\
& P2K & -0.305 \\
\hline
\end{tabular}

\section{DISCUSSION}

In the first stage of this research, namely qualitative analysis, the function is to observe the physical characteristics of salted fish samples. The data in Table 1 shows that physically, brown salted fish have a tendency to have a mushy texture. Meanwhile, white salted fish tended to have a hard texture, namely samples P2C, P3C, P1K, and P3K, which had a longer shelf life than other samples which were brownish in color and soft. Of course this is related to the water content in the salted fish. P2C, P3C, P1K, and P3K samples have less water content because they look drier and harder so that the activity of microorganisms is less. This is in accordance with the statement from Habibah (2014) that high water content can accelerate the process of spoilage in fish.

In preparation for quantitative analysis, a curve called a standard curve is made. This curve produces the equation of the line $y=0.2044 x+0.3304$ and $R 2=0.997$. This $R 2$ value indicates that the linearity level is very good, where the value is close to 1 (Baehaki et al., 2020). With this value, the line equation can be used to calculate the formaldehyde content in the sample.

Calculation of formaldehyde levels was carried out based on the resulting absorbance value. The data in Table 3 shows that of the 15 salted fish samples taken, 4 samples contained formaldehyde, namely P2C, P3C, P1K, and P3K samples with levels of $0.033-0.482 \mathrm{ppm}$. This shows that the use of formaldehyde is still being carried out by some producers. Whereas it is clearly stated in the Regulation of the Minister of Health of the Republic of Indonesia Number 722/Men.Kes/Per/lX/88 concerning Food Additives and Regulation of the Minister of Health Number 1168/Menkes/PER/X/1999 concerning Chemicals whose use is prohibited for food products. that the use of formaldehyde as a food preservative is strictly prohibited. This means that in the food there should not be any formaldehyde added. The results of this study have also strengthened the results of previous research conducted by Habibah (2014), Zakaria, Sulastri, and Sudding (2014), and Fatimah, Astuti, and Awalia (2017) which showed that there are still producers and traders who sell fish products that using formaldehyde as a preservative.

Another thing that needs to be observed from the results of this study is the relationship between qualitative and quantitative data. Where samples containing formaldehyde have a longer shelf life than other samples (see Table 1 and Table 3). Judging from the physical characteristics, the four samples containing formaldehyde had the same physical characteristics. This is in accordance with the statement from Hastuti 
(2017) that generally foods containing formaldehyde have characteristics, namely, they are brighter in color, not infested by flies, and have a harder texture. Of course this needs to be a concern, especially for the Indonesian government in preventing the abuse of formaldehyde. Because after all, formaldehyde is toxic which can have a negative effect on body health, and can even cause cancer and even death (Tang, et al., 2009; Freeman et al. 2009; Hauptmann et al. 2009; Scheuplein, 1985; Restani and Galli, 1991; Zhao, et al., 2021; Bernardini et al., 2020).

\section{CONCLUSION}

The use of formaldehyde as a food preservative is still carried out by some producers and traders. This is indicated by the data that from 15 samples of salted fish, there were 4 samples that were positive for formaldehyde. The four samples have the same characteristics, namely bright white color and hard texture. Of course this needs to be a concern for the government in supervising the use of formaldehyde in foodstuffs. This is because formaldehyde is very harmful to the health of the body when consumed. Toxic effects caused by formaldehyde can trigger cancer if consumed in large quantities. However, unfortunately this study did not include an assessment of the toxic effects that formaldehyde can cause. In addition, the confirmed area as a sampling location is still very limited. This is due to time and cost constraints. Of course, this is one of the weaknesses in this study. Therefore, this research would be better if the sampling area was expanded and deepened the study to analyze the toxic effects of the formaldehyde.

\section{REFERENCES}

Alsuhendra \& Ridawati. (2013). Bahan toksik dalam makanan. Bandung: PT Remaja Rosdakarya.

Astuti I. \& Tebai, P. (2018). Analisis formaldehyde ikan teri (stolephorus sp) asin di pasar tradisonal Kabupaten Gorontalo. Gorontalo Fisheries Journal, 1(1), 43-50. http://jurnal.unigo.ac.id/index.php/gfj/article/view/105

Baehaki, F., Rudibyani, R. B., Aeni, S. R. N., Perdana, R., and Aqmarina, S. N. (2020). Utilization of salacca zalacca seeds as chromium (VI) adsorbents. Periodico Tche Quimica, 17(34), 381-389.

Bernardini, L., Barbosa, E., Charão, M.F. \& Brucker, N. (2020). Formaldehyde toxicity reports from in vitro and in vivo studies: a review and updated data. Drug and Chemical Toxicology,

1-13. https://doi.org/10.1080/01480545.2020.1795190

Cahyadi, W. (2012). Analisis dan aspek kesehatan bahan tambahan pangan. Jakarta: PT Bumi Aksara.

Fatimah, S., Astuti, D.W. \& Awalia, N.H. (2017). Analisis formaldehyde pada ikan asin di pasar giwang dan Pasar Beringharjo Yogyakarta. Analit: Analytical and Environmental Chemistry, 2(1): 22-28. http://jurnal.fmipa.unila.ac.id/index.php/analit/article/view/1433

Freeman, B.L.E, et al. (2009). Mortality from lymphohematopoietic malignancies among workers in formaldehyde industries: the National Cancer Institute cohort. JNCI J Nat Cancer Inst, 101, 751-761. https://doi.org/10.1093/jnci/djp096

Habibah, P.Z.H. (2014). Identifikasi penggunaan formaldehyde pada ikan asin dan faktor perilaku penjual di pasar tradisonal Kota Semarang. UNNES Journal of Public Health, 2(3): 24-28. https://doi.org/10.15294/ujph.v2i3.3031

Hasmalina, N., Alfayed, M., Helvina, Siti, F., Ulfa, R., dan Mardhatila, A. (2018). Analisa Kadar Formaldehyde Dan Boraks Pada Tahu Dari Produsen Tahu di Lima Kecamatan di Kota Pekanbaru. Jurnal Photon, 8(2):37-44. http://ejurnal.umri.ac.id/index.php/photon/article/download/714/377

Hasna, M., Sangi, M.S., \& Wuntu, A.D. (2017). Analisis kandungan formaldehyde dan boraks pada ikan asin dan tahu dari 
pasar pinasungkulan manado dan pasar beriman tomohon. Jurnal MIPA UNSRAT Online, 6(2): 24-28. https://doi.org/10.35799/jm.6.2.2017.17073

Hastuti, E. (2017). Gambaran penggunaan formaldehyde pada ikan asin di pasar karangayu Kota Semarang. Cendekia, 2(5), 85-95.

Hauptmann, M., Stewart P.A., Lubin J.H. et al (2009). Mortality from lymphohematopoietic malignancies and brain cancer among embalmers exposed to formaldehyde. JNCl J Nat Cancer Inst, 101, 1696-1708. https://doi.org/10.1093/jnci/djp416

Heck, d.A., Casanova, M., \& Starr, T.B. (1990). Formaldehyde toxicity-new understanding. Critical Reviews in Toxicology, 20(6), 397-426. https://doi.org/10.3109/10408449009029329

Kurniawan, W. (2017). Urgensi Penerapan sistem jaminan keamanan perikanan. in: seminar nasional sains dan teknologi. [online] Jakarta: Universitas Muhammadiyah Jakarta. https://jurnal.umj.ac.id/index.php/ semnastek/article/view/2022 (Accessed 19 June 2020).

Male, Y.T., Letsoin, L.I., \& Siahaya, N.I. (2017). Analisis kandungan formaldehyde pada mie basah pada beberapa lokasi di Kota Ambon. Majalah Biam, 13(2): 5-10. http://ejournal.kemenperin.go.id/bpbiam/article/view/3530

Pursetyo, T.P., Thajaningsih, W, dan Pramono, H. (2015). Perbandingan morfologi kerang darah di perairan kenjeran dan perairan sedati. Jurnal IImiah Perikanan dan Kelautan, 7(1). http://dx.doi.org/10.20473/jipk.v7i1.11222

Regulation of the Minister of Health Number 1168/Menkes/PER/X/1999 concerning Chemicals whose use is prohibited for food products

Regulation of the Minister of Health of the Republic of Indonesia No. 722/Men.Kes/Per/IX/88 Regarding Food Additives

Restani, P. and Galli, C.L. (1991). Oral toxicity of formaldehyde and its derivatives. Critical Reviews in Toxicology, 21(5), 315-328. https://doi.org/10.3109/10408449109019569

Sari, S.A., Asterina, \& Adrial. (2014). Perbedaan kadar formaldehyde pada tahu yang dijual di pasar pusat kota dengan pinggiran Kota Padang. Jurnal Kesehatan Andalas, 3(3), 466-470. https://doi.org/10.25077/jka.v3i3.178

Scheuplein, R.J. (1985). Formaldehyde: The food and drug administration's perspective. Advances in Chemistry, 210 , Chapter 6, 237-345.

Sianturi, S.jr., Masinambow, V.A.J., \& Londa, A.T. (2018). dampak regulasi sektor perikanan tangkap ikan terhadap pertumbuhan pdrb di Kota Bitung. Jurnal Berkala Ilmiah Efisiensi, 18(1), $103-113$. https://ejournal.unsrat.ac.id/index.php/jbie/article/view/19848

Sinaga, E.J. (2009). analisis kandungan formaldehyde pada ikan asin kembung rebus di beberapa pasar tradisional Kota Medan. Medan: Fakultas Kesehatan Masyarakat, Universitas Sumatera Utara.

Tang, et al. (2009). Formaldehyde in China: Production, consumption, exposure levels, and health effects. Environment International, 35(8), 1210 -1224. https://doi.org/10.1016/j.envint.2009.06.002

Tatuh, H.A., Rorong, J. \& Sudewi, S. (2016). Analisis kandungan formaldehyde pada berbagai jenis ikan di Kota Manado. Pharmacon, 5(4): 162-167. https://ejournal.unsrat.ac.id/index.php/pharmacon/article/ download/13990/1 3562

Wardani, R.I. \& Mulasari, S.A. (2016). Identifikasi formaldehyde pada ikan asin ynag dijual dikawasan pantai teluk penyu Kabupaten Cilacap. Kesmas, 10(1), 15-24. https://www.neliti.com/publications/25034/ identifikasi-formaldehyde-pada-ikan-asin-yang-dijual-di-kawasan-pantai-teluk-penyu-k

Zakaria, B., Sulastri, T., \& Sudding. (2014). Analisis kandungan formaldehyde pada ikan asin katamba (lethrinus lentjan) yang beredar di Kota Makassar. Chemica: Jurnal Ilmiah Kimia dan Pendidikan Kimia, 15(2), 16-23. https://doi.org/10.35580/chemica.v15i2.4588

Zhao, Y., Magaña, L.C., Cui, H. et al. (2021). Formaldehyde-induced hematopoietic stem and progenitor cell toxicity in mouse lung and nose. Arch Toxicol 95, 693-701. https://doi.org/10.1007/s00204-020-02932-x 